\title{
Synthesis, structure and biological activity of silver(I) complexes of substituted imidazoles
}

\author{
Malachy McCann ${ }^{a}$, Robert Curran ${ }^{a}$, Marcia Ben-Shoshan ${ }^{a}$, Vickie McKee ${ }^{\mathrm{b}, *}$, Michael Devereux ${ }^{\mathrm{c}}$, \\ Kevin Kavanagh $^{\mathrm{d}}$, Andrew Kellett ${ }^{\mathrm{e}}$ \\ ${ }^{a}$ Department of Chemistry, National University of Ireland, Maynooth, Co. Kildare, Ireland \\ ${ }^{\mathrm{b}}$ Chemistry Department, Loughborough University, Loughborough, Leics. LE11 3TU, UK \\ ${ }^{\mathrm{c}}$ The Inorganic Pharmaceutical and Biomimetic Research Laboratory, Focas Institute, Dublin Institute of Technology, Kevin St., Dublin 2, Ireland \\ ${ }^{\mathrm{d}}$ Department of Biology, National University of Ireland, Maynooth, Co. Kildare, Ireland \\ ${ }^{\mathrm{e}}$ School of Chemical Sciences, Dublin City University, Glasnevin, Dublin 9, Ireland
}

\section{A R T I C L E I N F O}

\section{Article history:}

Received 30 January 2013

Accepted 26 March 2013

Available online 4 April 2013

\section{Keywords:}

Silver(I)

Imidazoles

Antimicrobial

In vitro

Galleria mellonella

In vivo

\begin{abstract}
A B S T R A C T
$\left[\mathrm{Ag}_{2}(9-\mathrm{aca})_{2}\right]$ (9-acaH = 9-anthracenecarboxylic acid) interacts with DMSO and a selection of substituted imidazoles giving $\left[\mathrm{Ag}_{4}(\mathrm{DMSO})_{4}(9-\mathrm{aca})_{4}\right]_{n}(\mathbf{1}),\left[\mathrm{Ag}(2-\mathrm{Me}-\mathrm{imH})_{2}(9-\mathrm{aca})\right](\mathbf{2}),\left[\mathrm{Ag}(4-\mathrm{Ph}-\mathrm{imH})_{2}(9-\mathrm{aca})\right](\mathbf{3})$, [Ag(2-Mebenz-imH $\left.)_{2}(9-a c a)\right](4),[\mathrm{Ag}(2-M e b e n z-i m)](6),[\mathrm{Ag}($ Benz-im) $)$ (7), [Ag(2-Ph-im)] (8) and [Ag(4,5-CN-im) (9) (2-Me-imH = 2-methylimidazole; 4-Ph-imH = 4-phenylimidazole; 2-Mebenz$\mathrm{imH}=2$-methylbenzimidazole; Benz-imH = benzimidazole; 2- $\mathrm{Ph}-\mathrm{imH}=2$-phenylbenzimidazole; 4,5$\mathrm{CN}$-imH $=4,5$-dicyanoimidazole). In the carboxylate/imidazole complexes $\mathbf{2 - 4}$, the imidazole ligand is in the neutral form, whilst in complexes 6-9 the imidazolate ligand is deprotonated and no carboxylate ligand is present. Attempted recrystallization of $\mathbf{4}$ from EtOH gives the metal-free, imidazolium salt, 2Mebenz-imH $\left.\mathrm{H}_{2}\right)\left(9\right.$-aca) $\mathrm{H}_{2} \mathrm{O}(\mathbf{5})$. The X-ray crystal structures of complexes $\mathbf{1}$ and $\mathbf{2}$ and the salt $\mathbf{5}$ were determined. Antimicrobial screening showed that the $\mathrm{Ag}(\mathrm{I})$ complexes were substantially more active against the fungus Candida albicans than the bacterial species, methicillin-resistant Staphylococcus aureus (MRSA) and Escherichia coli. Some of the complexes offer a good prognosis for Galleria mellonella (larvae of the greater wax moth) infected with a lethal dose of $C$. albicans cells.
\end{abstract}

(C) 2013 Elsevier Ltd. All rights reserved.

\section{Introduction}

Recent World Health Organization (WHO) publications [1,2] have highlighted the critical situation of antimicrobial drug resistance and that too few new compounds are being developed to combat infectious agents. In a recent publication, Lansdown chronicles the uses of silver-containing therapeutics in the treatment of bacterial, fungal and viral infections [3]. Besides its high bactericidal and fungicidal attributes, and in stark contrast to most other medicinally-active transition metal ions, $\mathrm{Ag}(\mathrm{I})$ ions are relatively well tolerated by mammalian cells [4].

It has been reported that coordinating imidazole and derivatised imidazoles to a $\mathrm{Ag}(\mathrm{I})$ centre generally enhances the antimicrobial effects of the metal ion. For example, Kleyi et al. [5] studied the antimicrobial activity of a family of 2-hydroxymethyl- $N$-alkylimidazole ligands and their $\mathrm{Ag}(\mathrm{I})$ complexes and found that whereas the metal-free ligands were poorly active against Escherichia coli and Candida albicans, imidazoles with long pendant alkyl chains displayed high activity against Staphylococcus

\footnotetext{
* Corresponding author. Tel.: +44 (0) 1509222565

E-mail address: V.McKee@lboro.ac.uk (V. McKee).
}

aureus and Bacillus spizizenii. $\mathrm{Ag}(\mathrm{I})$ complexes containing imidazole ligands with shorter alkyl chains were more active against $E$. coli, whilst those with longer chains displayed higher activity against B. spizizenii. The authors attributed the antimicrobial effect on E. coli and C. albicans solely to the $\mathrm{Ag}(\mathrm{I})$ ions since the metal-free ligands displayed poor activity against these organisms. They also concluded that the activity of the complexes containing ligands with longer alkyl chain lengths was due to a combination of the $\mathrm{Ag}(\mathrm{I})$ ion and the active imidazole.

We have previously synthesised and screened mononuclear, multinuclear and polymeric $\mathrm{Ag}(\mathrm{I})$ complexes comprising imidazole and N1-substituted imidazoles, and found that $\left[\mathrm{Ag}(\mathrm{imH})_{2.3}\left(\mathrm{CH}_{3-}\right.\right.$ $\left.\mathrm{CN})_{0.7}\right](9-\mathrm{aca}), \quad\left[\mathrm{Ag}_{6}(\mathrm{imH})_{4}(9-\mathrm{aca})_{6}(\mathrm{MeOH})_{2}\right], \quad\left\{\left[\mathrm{Ag}(1-\mathrm{Me}-\mathrm{im})_{2}\right]_{2}[-\right.$ $\left.\left.\mathrm{Ag}_{4}(9-\mathrm{aca})_{6}\right]\right\}, \quad\left\{\left[\mathrm{Ag}(1-\mathrm{Bu}-\mathrm{im})_{2}\right]_{2}\left[\mathrm{Ag}_{4}(9-\mathrm{aca})_{6}\right]\right\}$ and $[\mathrm{Ag}(\mathrm{apim})](9-$ aca) $\cdot \mathrm{H}_{2} \mathrm{O}$ (imH = imidazole; 1 -Me-im = 1-methylimidazole; 1 - $\mathrm{Bu}$ im =1-butylimidazole; apim =1-(3-aminoproply)imidazole; 9$\mathrm{acaH}=9$-anthracenecarboxylic acid) were all highly active, in vitro, against E. coli, S. aureus and C. albicans cells [6]. Moreover, in vivo studies conducted on larvae of the greater wax moth ( $\mathrm{Gal}$ leria mellonella) infected with a lethal dose of $C$. albicans cells revealed that pre- and post-administration of some of these $\operatorname{Ag}(\mathrm{I})$ complexes increased the chances of survival of the juveniles. Encouraged by these results, $\left[\mathrm{Ag}_{2}(9-\mathrm{aca})_{2}\right]$ has now been used as 


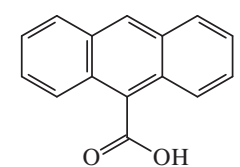

9-anthracenecarboxylic acid (9-acaH)

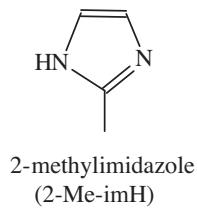
(2-Me-imH)

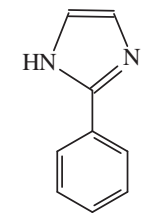

2-phenylimidazole (2-Ph-imH)<smiles>c1ccc(-c2c[nH]cn2)cc1</smiles>

4-phenylimidazole (4-Ph-imH)<smiles>N#Cc1nc[nH]c1C#N</smiles>

4,5-dicyanoimidazole $(4,5-\mathrm{CN}-\mathrm{imH})$

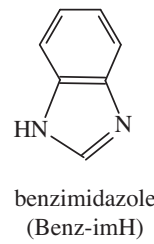

Fig. 1. Ligand structures. the starting material for the preparation of a new series of $\mathrm{Ag}(\mathrm{I})$ complexes containing relatively cheap, commercially available imidazole ligands carrying substituents at positions other than the pyrrole-type $\mathrm{N} 1$ atom of the ring (Fig. 1). In addition to their structural and physical properties, the in vitro and in vivo antimicrobial activities of the complexes are also reported.

\section{Experimental}

\subsection{Reagents and instrumentation}

Chemicals were purchased from commercial sources and were used without further purification. The syntheses of all silver complexes were conducted in the absence of light and the products were stored in the dark at all times. $\left[\mathrm{Ag}_{2}(9-\mathrm{aca})_{2}\right]$ was prepared from $\mathrm{K}^{+}(9-$ aca) ${ }^{-}$and $\mathrm{AgNO}_{3}$ in accordance with the literature method [6]. Infrared spectra (as $\mathrm{KBr}$ discs) were recorded in the region 4000$370 \mathrm{~cm}^{-1}$ on a Perkin Elmer System 2000 FT spectrometer. ${ }^{1} \mathrm{H}$ NMR spectra, recorded as solutions in deuterated dimethylsulfoxide $\left(\left(\mathrm{CD}_{3}\right)_{2} \mathrm{SO}\right)$, were recorded on a Bruker Avance spectrometer operating at $300 \mathrm{MHz}$ and a probe temperature of $25^{\circ} \mathrm{C}$. Microanalytical data were provided by the Microanalytical Laboratory, University College Dublin, Belfield, Dublin 4, Ireland.

\subsection{X-ray crystal structure determinations}

X-ray crystallographic data (Table 1 ) were collected at $150(2) \mathrm{K}$ on a Bruker APEX II diffractometer using Mo $K_{\alpha}$ radiation $(\lambda=0.71073 \AA)$ and semi-empirical absorption corrections were applied. The structures were solved by direct methods and refined on $F^{2}$ using all the reflections [7]. All of the non-hydrogen atoms were refined using anisotropic atomic displacement parameters. All hydrogen atoms were inserted at calculated positions using a riding model except for those bonded to oxygen or nitrogen in compound 3; these were located from difference maps and refined under geometric restraints. One of the two independent 9-aca groups in complex 1 was disordered, this was modelled as 60:40 occupancy of two overlapping sites.

\subsection{Biological screening}

E. coli, MRSA, C. albicans and G. mellonella (larvae of the greater wax moth) were sourced and stored as previously described [6].

Table 1

X-ray crystallographic data.

\begin{tabular}{|c|c|c|c|}
\hline Compound & 1 & 2 & 5 \\
\hline Formula & {$\left[\mathrm{Ag}_{4}(\mathrm{DMSO})_{4}(9-\mathrm{aca})_{4}\right]_{n}$} & {$\left[\mathrm{Ag}(4-\mathrm{Ph}-\mathrm{imH})_{2}(9-\mathrm{aca})\right]$} & $\left(2-M e b e n z-\mathrm{imH}_{2}\right)(9-\mathrm{aca}) \cdot \mathrm{H}_{2} \mathrm{O}$ \\
\hline Empirical formula & $\mathrm{C}_{68} \mathrm{H}_{60} \mathrm{Ag}_{4} \mathrm{O}_{12} \mathrm{~S}_{4}$ & $\mathrm{C}_{23} \mathrm{H}_{21} \mathrm{AgN}_{4} \mathrm{O}_{2}$ & $\mathrm{C}_{23} \mathrm{H}_{20} \mathrm{~N}_{2} \mathrm{O}_{3}$ \\
\hline Crystal system & monoclinic & monoclinic & orthorhombic \\
\hline Space group & $P 2_{1} / c$ & $C 2 / c$ & $P 2_{1} 2_{1} 2_{1}$ \\
\hline \multicolumn{4}{|l|}{ Unit cell dimension } \\
\hline$a(\AA)$ & $9.1304(7)$ & $19.8374(17)$ & $6.9251(8)$ \\
\hline$b(\AA)$ & $19.5875(14)$ & $15.2507(13)$ & $14.8341(17)$ \\
\hline$c(\AA)$ & $18.0502(13)$ & $14.4941(13)$ & $18.522(2)$ \\
\hline$\beta\left({ }^{\circ}\right)$ & $99.2280(10)$ & $110.140(1)$ & 90 \\
\hline$V\left(\AA^{3}\right)$ & $3186.3(4)$ & $4116.8(6)$ & $1902.7(4)$ \\
\hline$Z$ & 2 & 8 & 4 \\
\hline$F(000)$ & 1632 & 2000 & 784 \\
\hline Crystal size $\left(\mathrm{mm}^{3}\right)$ & $0.41 \times 0.09 \times 0.08$ & $0.28 \times 0.14 \times 0.13$ & $0.41 \times 0.08 \times 0.08$ \\
\hline Crystal description & yellow rod & colourless pyramid & colourless rod \\
\hline Refl collected & 30770 & 20857 & 16919 \\
\hline Unique reflection ( $R_{\text {int }}$ ) & $7311(0.0426)$ & $5142(0.0541)$ & $2241(0.0507)$ \\
\hline$\%$ Complete (to $\theta^{\circ}$ ) & $99.9(27.50)$ & $99.9(28.35)$ & $99.9(26.35)$ \\
\hline Data/restraints/param & $7311 / 711 / 518$ & $5142 / 0 / 273$ & $2241 / 0 / 260$ \\
\hline Goodness-of-fit (GOF) on $F^{2}$ & 1.027 & 1.030 & 1.046 \\
\hline$R_{1}, w R_{2}[I>2 \sigma(I)]$ & $0.0318,0.0702$ & $0.0345,0.0715$ & $0.0365,0.0853$ \\
\hline R1, wR2 (all data) & $0.0463,0.0770$ & $0.0541,0.0787$ & $0.0482,0.0917$ \\
\hline Residuals $\left(\mathrm{e} \AA^{-3}\right)$ & $0.821,-0.668$ & $0.680,-0.407$ & $0.308,-0.355$ \\
\hline
\end{tabular}


Routine protocols were used to determine the in vitro antibacterial and antifungal properties of the complexes [6]. G. mellonella were utilised to assess the in vivo toxicity of the complexes and to establish fungal pathogenicity $[6,8,9]$. Two in vivo antifungal treatment protocols were used to determine fungal pathogenicity [6]. For the prophylactic treatment, larvae were injected with a solution/ suspension of the test complex and after $1 \mathrm{~h}$ they were inoculated with a lethal dose of $C$. albicans cells. For the treatment of infection, larvae were first inoculated with a lethal dose of fungal cells and after $1 \mathrm{~h}$ the test solution/suspension was administered. Larvae survival was monitored $72 \mathrm{~h}$ following the treatment protocols.

\subsection{Chemical synthesis}

\subsection{1. $\left[\mathrm{Ag}_{4}(\mathrm{DMSO})_{4}(9-a c a)_{4}\right]_{n}(\mathbf{1})$}

[ $\left.\mathrm{Ag}_{2}(9-\mathrm{aca})_{2}\right]$ (0.100 g, 0.15 mmoles $)$ was dissolved in dimethylsulfoxide $\left(4 \mathrm{~cm}^{3}\right)$ and the mixture heated to $80{ }^{\circ} \mathrm{C}$ for $20 \mathrm{~min}$. Ethanol $\left(15 \mathrm{~cm}^{3}\right)$ was added and the solution was brought to reflux and then filtered. The filtrate was left to stand and after 3 days yellow, needle-like crystals were collected by filtration, washed with ethanol and allowed to air-dry (0.062 g yield 50\%). Soluble in $\mathrm{MeCN}$ and DMSO. Molecular weight $814.44 \mathrm{~g} \mathrm{~mol}^{-1}$. Anal. Calc.: C, 50.14; H, 3.71. Found: C, 50.22; H, 3.70\%. IR $\left(\mathrm{cm}^{-1}\right)$ : 3411, 3050, 1620 , $1587,1565,1538,1427,1389,1320,1276,1018 .{ }^{1} \mathrm{H}$ NMR $(\delta$, DMSO): $8.45(\mathrm{~s}, 1 \mathrm{H}) ; 8.18(\mathrm{~m}, 2 \mathrm{H}) ; 8.05(\mathrm{~m}, 2 \mathrm{H}) ; 7.48(\mathrm{~m}, 4 \mathrm{H})$; $2.56(\mathrm{~s}, 6 \mathrm{H})$.

\subsection{2. $\left[\mathrm{Ag}(2-\mathrm{Me}-\mathrm{imH})_{2}(9-a c a)\right](2)$}

$\left[\mathrm{Ag}_{2}(9-\mathrm{aca})_{2}\right](0.068 \mathrm{~g}, 0.10 \mathrm{mmoles})$ was dissolved in acetonitrile $\left(10 \mathrm{~cm}^{3}\right)$ and a solution of 2-methylimidazole $(0.035 \mathrm{~g}$, 0.40 mmoles $)$ in acetonitrile $\left(2 \mathrm{~cm}^{3}\right)$ was added dropwise with stirring. A white precipitate immediately formed which quickly redissolved. The solution was stirred for $1 \mathrm{~h}$ at room temperature and a yellow precipitate formed. The yellow solid was collected by filtration, washed with a small portion of ethanol and diethyl ether. The yellow solid was recrystallised from acetonitrile to yield light-yellow crystals suitable for X-ray crystal analysis ( $0.050 \mathrm{~g}$ yield $51 \%$ ). Soluble in $\mathrm{MeOH}, \mathrm{EtOH}, \mathrm{MeCN}$ and DMSO. Molecular weight: $493.31 \mathrm{~g} \mathrm{~mol}^{-1}$. Anal. Calc.: C, 56.00; H, 4.29; N, 11.36. Found: C, $55.70 ; \mathrm{H}, 4.29 ; \mathrm{N}, 11.08 \%$. IR $\left(\mathrm{cm}^{-1}\right): 3047,2909,2855,2685$, 1590, 1554, 1484, 1422, 1386, 1358, 1318, 1275, 1166, 1130, 1113, 1013. ${ }^{1} \mathrm{H}$ NMR ( $\delta$, DMSO): $8.43(\mathrm{~s}, 1 \mathrm{H}) ; 8.20(\mathrm{~m}, 2 \mathrm{H}) ; 8.08$ (m, 2H); $7.50(\mathrm{~m}, 4 \mathrm{H}) ; 7.08(\mathrm{~s}, 4 \mathrm{H}) ; 2.47(\mathrm{~s}, 6 \mathrm{H})$.

\subsection{3. $\left[\mathrm{Ag}(4-\mathrm{Ph}-\mathrm{imH})_{2}(9-a c a)\right](3)$}

$\left[\mathrm{Ag}_{2}(9-\mathrm{aca})_{2}\right](0.658 \mathrm{~g}, 1.00 \mathrm{mmoles})$ was dissolved in hot acetonitrile $\left(100 \mathrm{~cm}^{3}\right)$ and the solution was filtered to remove any undissolved material. 4-Phenylimidazole $(0.438 \mathrm{~g}, 3.04 \mathrm{mmoles})$ was dissolved in hot acetonitrile and added to the hot solution of $\left[\mathrm{Ag}_{2}(9-\mathrm{aca})_{2}\right]_{n}$. The mixture was stirred at room temperature for $0.5 \mathrm{~h}$. The suspension was filtered and the beige precipitate was washed with a small portion of cold ethanol and air-dried (0.887 g yield $81 \%)$. Soluble in DMSO. Molecular weight: $473.32 \mathrm{~g} \mathrm{~mol}^{-1}$. Calc.: C, 64.19; $\mathrm{H}, 4.08 ; \mathrm{N}, 9.07 \%$. Found: C, 63.74; H, 4.14; N, 8.88\%. IR $\left(\mathrm{cm}^{-1}\right): 3430,3280,3129,3057$, 2977, 2821, 2709, 2633, 1614, 1579, 1553, 1495, 1442, 1424, 1387, 1355, 1318, 1273, 1180, 1136, 1073, 1029, 1012. ${ }^{1} \mathrm{H}$ NMR ( $\delta$, DMSO): $8.47(\mathrm{~s}, 1 \mathrm{H}) ; 8.14(\mathrm{~m}, 2 \mathrm{H}) ; 8.06(\mathrm{~m}, 2 \mathrm{H}) ; 7.88(\mathrm{~s}, 2 \mathrm{H})$; $7.83(\mathrm{~s}, 4 \mathrm{H}) ; 7.59(\mathrm{~s}, 2 \mathrm{H}) ; 7.48(\mathrm{~m}, 4 \mathrm{H}) ; 7.39(\mathrm{t}, 4 \mathrm{H}) ; 7.25(\mathrm{t}, 2 \mathrm{H})$.

\subsection{4. $\left[\mathrm{Ag}(2-\mathrm{Mebenz} \text {-imH })_{2}(9-a c a)\right](4)$}

$\left[\mathrm{Ag}_{2}(9-\mathrm{aca})_{2}\right](1.000 \mathrm{~g}, 1.52 \mathrm{mmoles})$ was dissolved in hot acetonitrile $\left(100 \mathrm{~cm}^{3}\right)$ and the solution was filtered to remove any undissolved material. The filtrate was brought to reflux and a solution of 2-methylbenzimidazole $(0.804 \mathrm{~g}, 6.08 \mathrm{mmoles})$ in hot acetonitrile $\left(30 \mathrm{~cm}^{3}\right)$ was added. A white precipitate immediately formed. The suspension was removed from the heat source and was stirred at room temperature for $1 \mathrm{~h}$. The beige solid was filtered off, washed with a small portion of cold ethanol and air-dried (1.562 $\mathrm{g}$ yield $87 \%)$. Soluble in hot $\mathrm{MeOH}$ and DMSO. Molecular weight: $461.32 \mathrm{~g} \mathrm{~mol}^{-1}$. Anal. Calc.: C, 62.74; H, 4,25; N, 9.44. Found: C, 62.40; H, 4.17; N, 9.44\%. IR $\left(\mathrm{cm}^{-1}\right)$ : 3446, 3047, 2524, $1888,1625,1599,1558,1532,1456,1427,1388,1318,1282$, $1223,1041,1005 .{ }^{1} \mathrm{H}$ NMR $(\delta$, DMSO): $8.63(\mathrm{~s}, 1 \mathrm{H}) ; 8.09(\mathrm{~m}, 2 \mathrm{H})$; $8.03(\mathrm{~s}, 2 \mathrm{H}) ; 7.56(\mathrm{~m}, 4 \mathrm{H}) ; 7.49(\mathrm{~m}, 4 \mathrm{H}) ; 7.15(\mathrm{~m}, 4 \mathrm{H})$. The signal for the protons of the methyl groups are masked by the large residual peak for non-deuterated DMSO ( $c a .2 .5 \mathrm{ppm}$ ).

\subsection{5. (2-Mebenz-im $\left.\mathrm{H}_{2}\right)(9-a c a) \cdot \mathrm{H}_{2} \mathrm{O}(5)$}

In an attempt to recrystallise $\left[\mathrm{Ag}(2-\mathrm{Mebenz}-\mathrm{imH})_{2}(9-\mathrm{aca})\right](4)$ from ethanol the silver-free, monohydrate salt, (5), crystallised and was subsequently characterised using X-ray crystallography.

\subsection{6. $[\mathrm{Ag}(2-\mathrm{Mebenz}$-im $)](\mathbf{6})$}

$\left[\mathrm{Ag}_{2}(9-\mathrm{aca})_{2}\right](0.500 \mathrm{~g}, 0.76 \mathrm{mmoles})$ was suspended in methanol $\left(50 \mathrm{~cm}^{3}\right)$ at room temperature. 2-Methylbenzimidazole $\left(0.201 \mathrm{~g}, 1.52\right.$ mmoles) was dissolved in methanol $\left(10 \mathrm{~cm}^{3}\right)$ and added to the stirring suspension of $\left[\mathrm{Ag}_{2}(9-\mathrm{aca})_{2}\right]$. The mixture was heated and a beige precipitate formed. The solid was filtered while hot, washed with methanol and allowed to air-dry $(0.288 \mathrm{~g}$ yield 79\%). Insoluble in water and all common solvents. Molecular weight: $239.04 \mathrm{~g} \mathrm{~mol}^{-1}$. Anal. Calc.: C, 40.19; H, 2.96; N, 11.72. Found: C, 40.27; H, 2.97; N, 11.24\%. IR $\left(\mathrm{cm}^{-1}\right)$ : 3434, 3056, 3025 , 2915, 1868, 1751, 1608, 1579, 1473, 1448, 1397, 1285, 1226, 1148, 1110, 1076, 1002.

\subsection{7. $[\mathrm{Ag}($ Benz-im $)](7)$}

$\left[\mathrm{Ag}_{2}(9-\mathrm{aca})_{2}\right](0.200 \mathrm{~g}, 0.30 \mathrm{mmoles})$ was suspended in methanol $\left(40 \mathrm{~cm}^{3}\right)$ at room temperature and a solution of benzimidazole $(0.072 \mathrm{~g}, 0.60 \mathrm{mmoles})$ in methanol $\left(5 \mathrm{~cm}^{3}\right)$ was added to the suspension. A beige precipitate formed and the suspension was stirred at room temperature for $0.5 \mathrm{~h}$. The beige solid was filtered, washed with cold methanol and air-dried (0.093 g yield 68\%). Insoluble in water and all common solvents. Molecular weight: $225.01 \mathrm{~g} \mathrm{~mol}^{-1}$. Anal. Calc.: C, 37.36; H, 2.24; N, 12.45. Found: C, 37.65; H, 2.29; N, 11.97\%. IR ( $\left.\mathrm{cm}^{-1}\right): 3443,3073,1759,1609,1584,1463,1453,1365$, 1300, 1281, 1239, 1185, 1145, 1113, 1015, 999.

\subsection{8. $[\mathrm{Ag}(2-\mathrm{Ph}$-im $)](\boldsymbol{8})$}

$\left[\mathrm{Ag}_{2}(9-\mathrm{aca})_{2}\right](0.500 \mathrm{~g}, 0.76 \mathrm{mmoles})$ was dissolved in hot acetonitrile $\left(40 \mathrm{~cm}^{3}\right)$ and the solution was filtered to remove any undissolved material. 2-Phenylimidazole $(0.219 \mathrm{~g}, 1.52 \mathrm{mmoles})$ was dissolved in hot acetonitrile $\left(20 \mathrm{~cm}^{3}\right)$ and this was added to the hot $\left[\mathrm{Ag}_{2}(9-\mathrm{aca})_{2}\right]$ solution. The resulting suspension was stirred at room temperature for $0.25 \mathrm{~h}$. The beige precipitate was filtered, washed with ethanol and air-dried (0.246 g yield 64\%). The complex was only slightly soluble in DMSO.

Molecular weight: $251.05 \mathrm{~g} \mathrm{~mol}^{-1}$. Anal. Calc.: C, 43.06; H, 2.82; $\mathrm{N}, 11.16$. Found: C, 43.62; H, 2.81; N, 10.58\%. IR $\left(\mathrm{cm}^{-1}\right): 3445$, $3040,1601,1578,1482,1458,1413,1318,1298,1280,1147$, 1074, 1023. ${ }^{1} \mathrm{H}$ NMR $(\delta$, DMSO): $7.92(\mathrm{~d}, 2 \mathrm{H}) ; 7.41(\mathrm{t}, 2 \mathrm{H}) ; 7.33$ (m, 1H); $7.24(\mathrm{~s}, 1 \mathrm{H}) ; 7.02(\mathrm{~s}, 1 \mathrm{H})$.

\subsection{9. $[\mathrm{Ag}(4,5-\mathrm{CN}-\mathrm{im})](\mathbf{9})$}

$\left[\mathrm{Ag}_{2}(9-\mathrm{aca})_{2}\right](0.500 \mathrm{~g}, 0.76 \mathrm{mmoles})$ was dissolved in hot acetonitrile $\left(50 \mathrm{~cm}^{3}\right)$ and the solution filtered to remove any undissolved material. 4,5-Dicyanoimidazole $(0.359 \mathrm{~g}, 3.04 \mathrm{mmoles})$ was dissolved in acetonitrile $\left(5 \mathrm{~cm}^{3}\right)$ and added to the hot $\left[\mathrm{Ag}_{2}(9-\mathrm{aca})_{2}\right]$ solution. A beige precipitate immediately formed and the suspension was stirred at room temperature for $1 \mathrm{~h}$. The beige solid was filtered, washed with a small portion of cold ethanol and air-dried (0.240 g yield 70\%). Insoluble in water and all 
common solvents. Molecular weight: $224.97 \mathrm{~g} \mathrm{~mol}^{-1}$. Anal. Calc.: C, 26.69; H, 0.49; N, 24.91. Found: C, 26.62; H, 0.41; N, 24.59\%. IR $\left(\mathrm{cm}^{-1}\right): 3534,2227,2176,1748,1720,1583,1492,1471,1457$, $1438,1321,1303,1283,1250,1115,1105,958,878,861$.

\section{Results and discussion}

\subsection{Synthesis and characterization}

In our previous work [6] involving the reaction of $\left[\mathrm{Ag}_{2}(9-\mathrm{aca})_{2}\right]$ with imidazole and imidazoles substituted at the 1-position (pyrrole-type nitrogen, N1), it was found that slight changes in either the reaction solvent or the structure of the imidazole ligand had a marked and somewhat unpredictable effect on the composition of the isolated complex. An overriding structural theme amongst the complexes $\left[\mathrm{Ag}(\mathrm{imidH})_{2.3}\left(\mathrm{CH}_{3} \mathrm{CN}\right)_{0.7}\right](9$-aca $), \quad\left[\mathrm{Ag}_{6}(\mathrm{imidH})_{4}(9-\right.$ aca $\left.)_{6}(\mathrm{MeOH})_{2}\right], \quad\left\{\left[\mathrm{Ag}(1-\mathrm{Me}-\mathrm{im})_{2}\right]_{2}\left[\mathrm{Ag}_{4}(9-\mathrm{aca})_{6}\right]\right\}$ and $\{[\mathrm{Ag}(1-\mathrm{Bu}-$ $\left.\left.\mathrm{im})_{2}\right]_{2}\left[\mathrm{Ag}_{4}(9-\mathrm{aca})_{6}\right]\right\}$, was the prevelance of bis(imidazole)silver(I) entities, in which two neutral imidazole ligands coordinate via their imine $\mathrm{N}$-atoms in an almost linear $\mathrm{N}-\mathrm{Ag}-\mathrm{N}$ fashion. Similarly, $[\mathrm{Ag}(\mathrm{apim})](9-\mathrm{aca}) \cdot \mathrm{H}_{2} \mathrm{O}[6]$ and $[\mathrm{Ag}($ apim $)] \mathrm{ClO}_{4}[10]$ had the imine nitrogen of one apim and the nitrogen of the pendant amine function of a neighbouring apim coordinated to the metal centre, with the $\mathrm{N}-\mathrm{Ag}-\mathrm{N}$ bond angle within the polymeric framework being $\mathrm{ca}$. $177^{\circ}$. Additionally, the imidazole ligands in $\left[\mathrm{Ag}(\mathrm{imH})_{2.3}\left(\mathrm{CH}_{3-}\right.\right.$ $\left.\mathrm{CN})_{0.7}\right](9-\mathrm{aca})$ and $\left[\mathrm{Ag}_{6}(\mathrm{imH})_{4}(9-\mathrm{aca})_{6}(\mathrm{MeOH})_{2}\right]$ coordinate as neutral molecules (pyrrole N1 not deprotonated). In the present work, where $\left[\mathrm{Ag}_{2}(9-\mathrm{aca})_{2}\right]$ has been reacted with a range of imidazoles bearing substituents at positions other than $\mathrm{N} 1$, it is again apparent that relatively minor variations in the structure of the incoming imidazole ligand, and in some cases the reaction solvent, can dramatically affect product formulation. Furthermore, some of the imidazoles are seen to deprotonate at the pyrrole N1 atom to give a heterocyclic, anionic ligand and thus eliminating the requirement for a 9 -aca ${ }^{-}$anion.

Synthetic routes to the new complexes are summarised in Scheme 1. $\left[\mathrm{Ag}_{4}(\mathrm{DMSO})_{4}(9-\mathrm{aca})_{4}\right]_{n}(\mathbf{1})$ was readily prepared in $50 \%$ yield by heating $\left[\mathrm{Ag}_{2}(9-\mathrm{aca})_{2}\right]$ in DMSO and ethanol (Scheme 1 ). The X-ray crystal structure of $\mathbf{1}$ was determined (Table 1 ) and selected bond lengths and angles are given in Table 2 . Although the asymmetric unit is $\left\{\mathrm{Ag}_{2}(9-\mathrm{aca})_{2}(\mathrm{DMSO})_{2}\right\}$, the complex is probably better described as a polymer made up of centrosymmetric tetranuclear $\left[\mathrm{Ag}_{4}(9-\mathrm{aca})_{4}(\mathrm{DMSO})_{2}\right]$ units linked into chains by bridging two further DMSO ligands (Fig. 2). The short Ag1-Ag2 and longer Ag1Ag1' bond lengths in 1 (2.9144(4) and 3.1468(5) $\AA$, respectively) contrast with short and long metal-metal distances in the polymeric starting material, $\left[\mathrm{Ag}_{2}(9-\mathrm{aca})_{2}\right]$ (2.8508(9) and 3.657(1) $\AA$, respectively) [11]. In 1, each carboxylate group forms a $\mu-1,3$-bridge between $\mathrm{Ag} 1$ and $\mathrm{Ag} 2$, additionally $\mathrm{O} 11$ is a single atom bridge between $\mathrm{Ag} 1$ and $\mathrm{Ag} 1^{\prime}$ while $\mathrm{O} 31$ and $\mathrm{O} 32$ bind to $\mathrm{Ag} 1$ in chelate fashion. The DMSO ligand containing 01 bridges $\mathrm{Ag} 1$ and $\mathrm{Ag} 2^{\prime}$ within a tetranuclear subunit and the second DMSO, which contains $\mathrm{O} 2$, links these units into chains running parallel to the $a$ axis by bridging $\mathrm{Ag} 2$ and $\mathrm{Ag} 2$ " (Fig. 3). The average $\mathrm{Ag}-\mathrm{O}$ bonds for the carboxylate and DMSO ligands in 1 are similar (2.423 and $2.448 \AA$, respectively), but are both somewhat longer than the $\mathrm{Ag}-\mathrm{O}$ (carboxylate) bonds in $\left[\mathrm{Ag}_{2}(9-\mathrm{aca})_{2}\right]$ (average $2.293 \AA$ for the carboxylate bridging bidentate and $\mathrm{O}$-bridging bonds). These longer metal-oxygen (carboxylate) bond lengths in $\mathbf{1}$ may be a consequence of the increased number of donor atoms (increased electron density) surrounding the metal centres.

The IR spectrum of $\mathbf{1}$ is very similar to that of $\left[\mathrm{Ag}_{2}(9-\mathrm{aca})_{2}\right]$ apart from the inclusion of the bands associated with the DMSO ligands. A band is observed at $708 \mathrm{~cm}^{-1}$ for the symmetric stretching vibration of the $S=0$ moiety along with a strong band at $955 \mathrm{~cm}^{-1}$ corresponding to the $\mathrm{S}-\mathrm{CH}_{3}$ rocking vibration of the methyl groups [12]. The carboxylate $v_{(\mathrm{OCO}) \text { asym }}$ and $v_{(\mathrm{OCO}) \text { sym }}$ stretching vibrations occur at 1587 and $1427 \mathrm{~cm}^{-1}$, respectively, giving a $\Delta_{\text {(OCO) }}$ value of $160 \mathrm{~cm}^{-1}$. Using this value it is not possible to identify the carboxylate coordination mode as predictions with $\Delta_{(\mathrm{OCO})}$ values of $c a$. $165 \mathrm{~cm}^{-1}$ have been shown to be untrustworthy [13].

The ${ }^{1} \mathrm{H}$ NMR spectrum of the starting material, $\left[\mathrm{Ag}_{2}(9-\mathrm{aca})_{2}\right]$, which exhibits peaks for the aromatic protons at $8.44(\mathrm{~s}, 2 \mathrm{H})$, $8.18(\mathrm{~m}, 4 \mathrm{H}), 8.03(\mathrm{~m}, 4 \mathrm{H})$ and $7.47 \mathrm{ppm}(\mathrm{m}, 8 \mathrm{H})$, is very similar to that of $\left[\mathrm{Ag}_{4}(\mathrm{DMSO})_{4}(9-\mathrm{aca})_{4}\right]_{n}(\mathbf{1})$, the only difference being the presence of a singlet at $2.56 \mathrm{ppm}$ for the methyl groups of the DMSO ligands. It is believed that the DMSO ligands dissociate in solution as the position of this singlet is unchanged when compared to uncoordinated DMSO. Coordination to the silver ion is expected to cause a shielding of the DMSO methyl protons but this is not evident from the spectrum.

$\left[\mathrm{Ag}(2-\mathrm{Me}-\mathrm{imH})_{2}(9-\mathrm{aca})\right](2)$ was synthesised from $\left[\mathrm{Ag}_{2}(9-\mathrm{aca})_{2}\right]$ and 2 -methylimidazole (2-Me-imH) in 51\% yield using acetonitrile as the reaction solvent (Scheme 1). Complex 2 was recrystallised from acetonitrile and the X-ray crystal structure solved (Figs. 4-6 and Table 2 ). In $\mathbf{2}$, the $\mathrm{Ag}(\mathrm{I})$ ion is coordinated to the imine nitrogen atoms of the two imidazole rings and also to one carboxylate oxygen atom of the anthracene ligand. This monodentate $\mathrm{Ag}-\mathrm{O}$ bond length $(2.4941(19) \AA)$ is significantly longer than the average $\mathrm{Ag}$ $\mathrm{O}$ distance for the bridging bidentate and O-bridging bonds in $\left[\mathrm{Ag}_{2}(9-\mathrm{aca})_{2}\right](2.293 \AA)$. The average $\mathrm{Ag}-\mathrm{N}$ bond length in 2 $(2.113 \AA$ ) is similar to that found for the ordered, transoid imidazoles in $\left[\mathrm{Ag}(\mathrm{imH})_{2.3}\left(\mathrm{CH}_{3} \mathrm{CN}\right)_{0.7}\right](9$-aca) $(2.126 \AA)$ and also to the

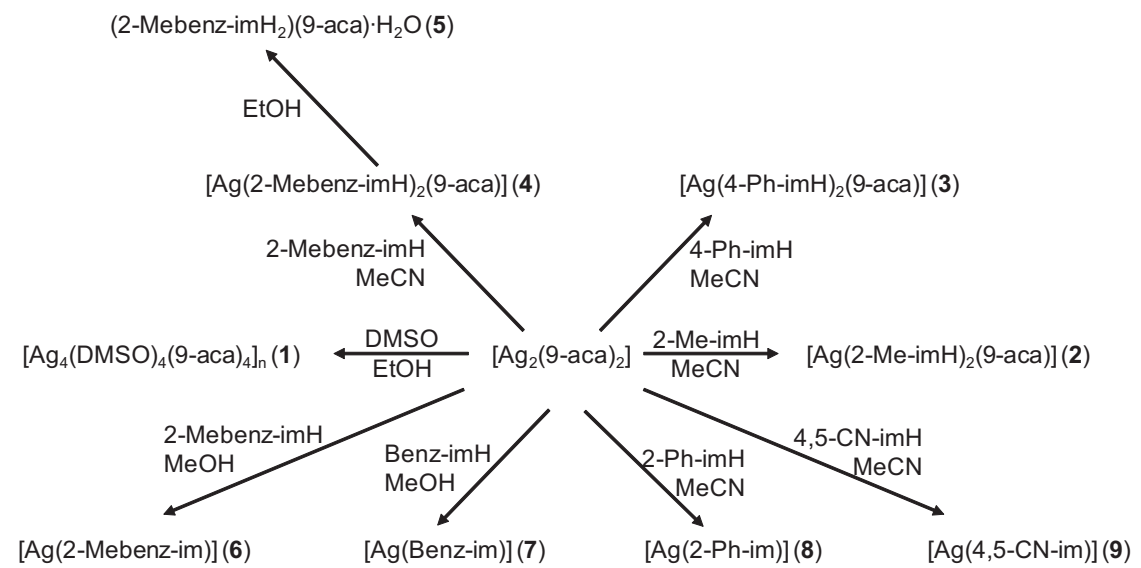

Scheme 1. 
Table 2

Selected bond lengths $(\AA)$ and angles $\left(^{\circ}\right)$.

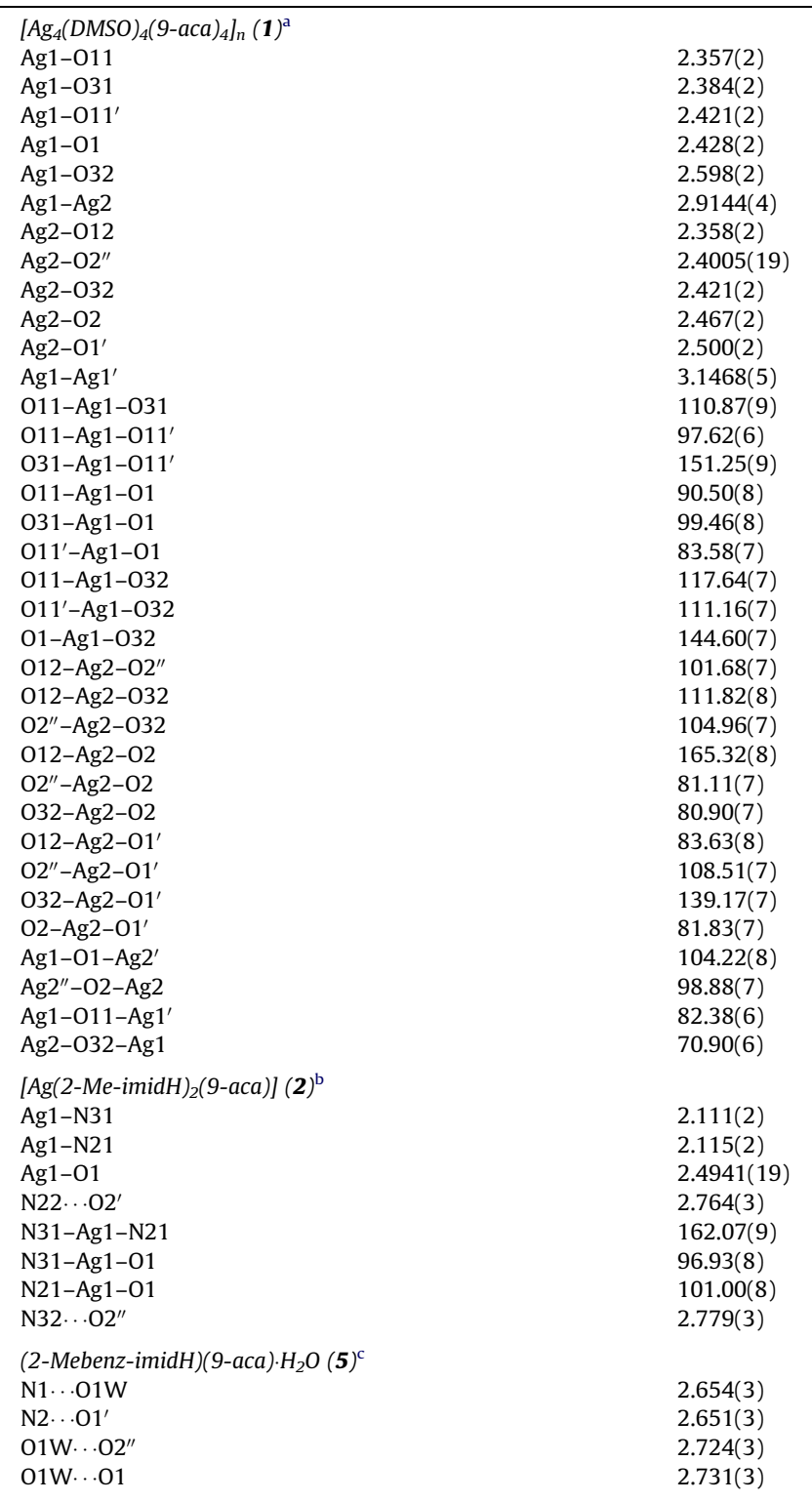

a Symmetry transformations used to generate equivalent atoms: ' $=-x+1,-y+1$, $-z+1 ; "=-x,-y+1,-z+1$.

b Symmetry transformations used to generate equivalent atoms: ' $=x+1 / 2$, $-y+1 / 2, z+1 / 2 ; "=x,-y, z+1 / 2$.

c Symmetry transformations used to generate equivalent atoms: ' $=-x, y-1 / 2$, $-z+3 / 2 ; "=x-1, y, z$

$\mathrm{Ag}-\mathrm{N}$ bonds in $\left[\mathrm{Ag}_{6}(\mathrm{imH})_{4}(9-\mathrm{aca})_{6}(\mathrm{MeOH})_{2}\right](2.088 \AA)$. As is the case in the latter two complexes, the imidazole ligands in $\mathbf{2}$ are coordinated approximately linearly to each other $(\mathrm{N}(31)-\mathrm{Ag}(1)-$ $\mathrm{N}(21)$ bond angle of $\left.162.07(9)^{\circ}\right)$ with the 9 -aca ${ }^{-}$ligand almost perpendicular $\left(\mathrm{N}(31)-\mathrm{Ag}(1)-\mathrm{O}(1)\right.$ bond angle of $\left.96.93(8)^{\circ}\right)$. The silver ion does not interact significantly with other donors or with neighbouring silver ions (closest Ag...Ag distance is 4.1930(5) $\AA$ ). The methyl groups at the 2-position on the imidazole ring are in a cis-conformation to each other and lie approximately perpendicular to the plane of the anthracene ring (Fig. 5).

Three sets of interactions define the packing of the molecules in the crystal lattice. The non-coordinated carboxylate oxygen atom (O2) is hydrogen bonded to the imidazole $\mathrm{NH}$ groups of two neighbouring molecules (Fig. 5 and Table 2), this generates a

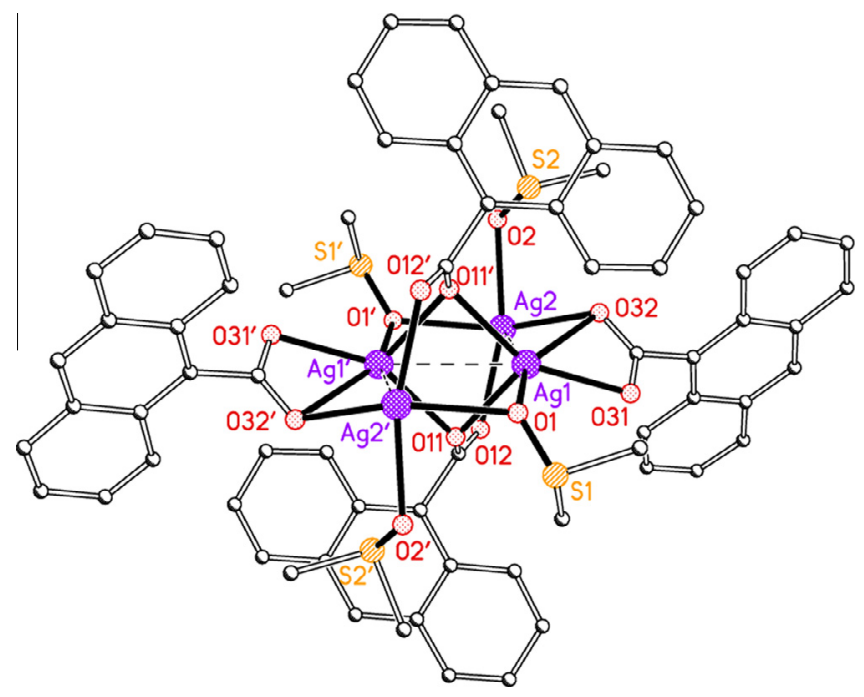

Fig. 2. Structure of a tetrameric unit of $\mathbf{1}$. Ag-Ag interactions shown as dashed lines and atoms generated by symmetry operations are indicated by: ' $=1-x, 1-y$, $1-z$

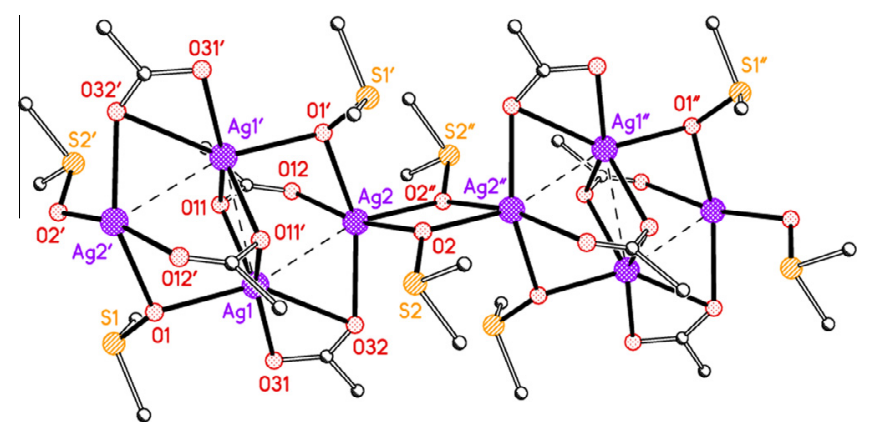

Fig. 3. Two subunits of $\mathbf{1}$ linked by bridging DMSO ligands (carbon atoms of the 9aca ligands omitted for clarity). Ag-Ag interactions shown as dashed lines and atoms generated by symmetry operations are indicated by: ' $=1-x, 1-y, 1-z$ and “ $=-x, 1-y, 1-z$.

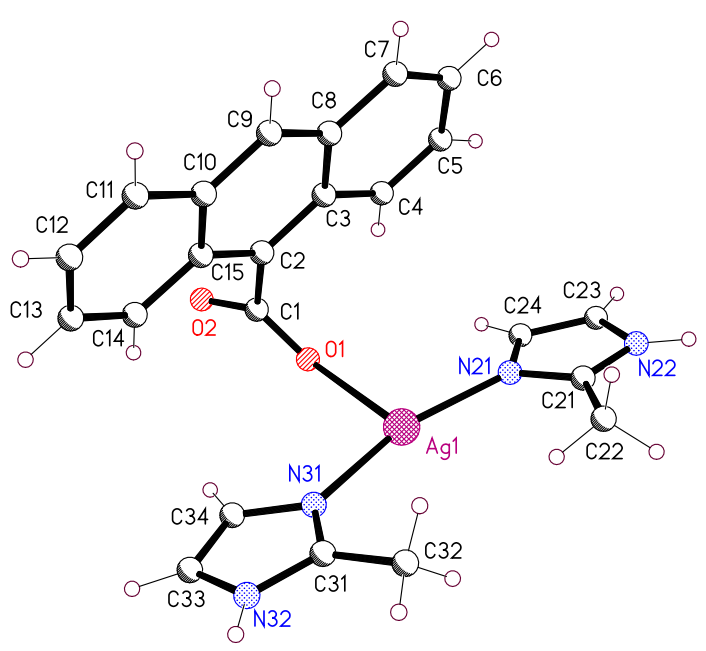

Fig. 4. Perspective view of $\left[\mathrm{Ag}(2-\mathrm{Me}-\mathrm{imH})_{2}(9-\mathrm{aca})\right](2)$.

three-dimensional hydrogen bonded network. There are also two sets of $\pi-\pi$ interactions: First the imidazole groups on adjacent molecules are paired (under $1-x,-y, 2-z$ ) so that the mean 


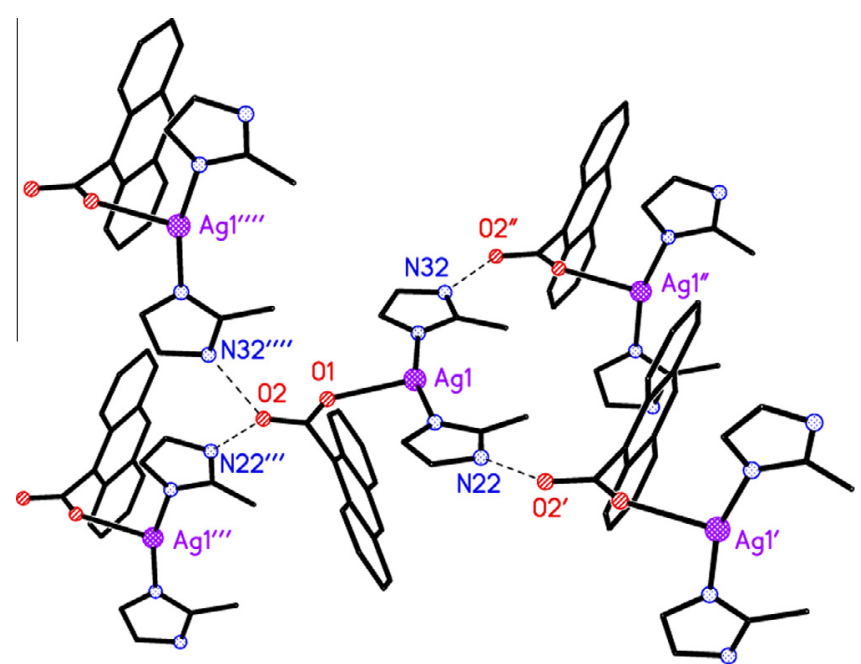

Fig. 5. Intermolecular H-bonding (shown as dashed lines) in 2. Symmetry codes: $1 / 2+x, 1 / 2-y, 1 / 2+z ; "$ ' $x,-y, 1 / 2+z ; / I I-1 / 2+x, 1 / 2-y,-1 / 2+z ; / I I I,-y,-1 / 2+z$.

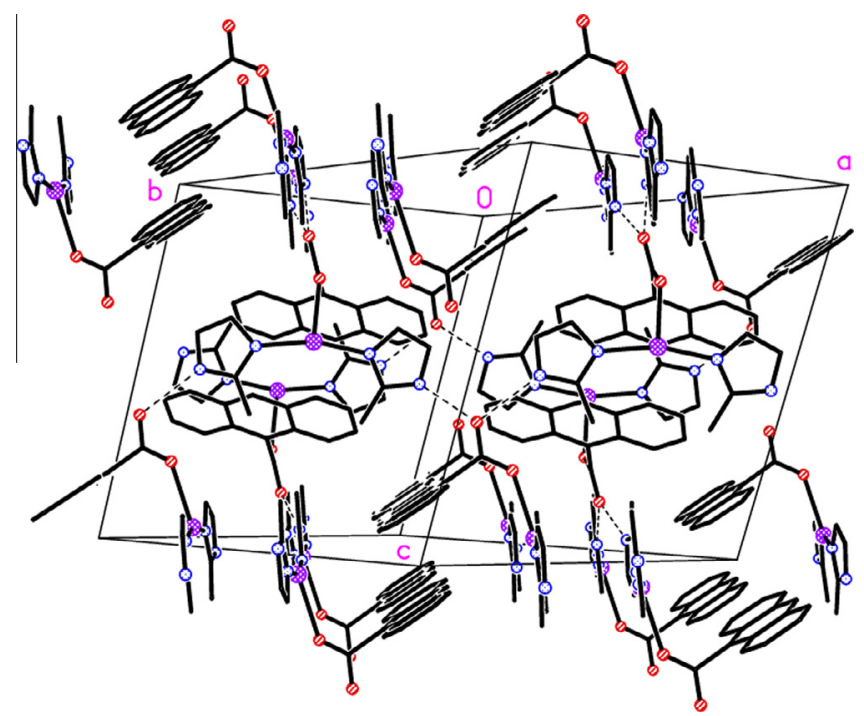

Fig. 6. Packing diagram for 2 showing $\pi-\pi$ interactions (hydrogen bonds shown as dashed lines).

interplanar distance is $3.33 \AA$ and the centroid-centroid distance is $3.52 \AA$. Neighbouring anthracene groups are also paired, with $\pi-\pi$ overlap of their outer rims (C8-C12 and C10-C10, 3.354 and $3.363 \AA$, respectively under symmetry operation $1 / 2-x, 1 / 2-y$, $2-z$ ). Together, these interactions generate $\pi-\pi$-linked chains parallel to the $a b$ diagonals (Fig. 6).

The IR spectrum of 2 has bands at 3047 and $1113 \mathrm{~cm}^{-1}$ representing the $\mathrm{N}-\mathrm{H}$ and $\mathrm{C}-\mathrm{N}$ stretching vibrations of the imidazole ligand, respectively. Bands are also evident at 1622, 762 and $734 \mathrm{~cm}^{-1}$ for the vibrations of the anthracene ring system $[12,14]$. The $v_{(\mathrm{OCO}) \text { asym }}$ and $v_{(\mathrm{OCO}) \text { sym }}$ vibrations occur at 1590 and $1421 \mathrm{~cm}^{-1}$, respectively, giving a $\Delta_{(\text {OCO })}$ value of $169 \mathrm{~cm}^{-1}$.

The ${ }^{1} \mathrm{H}$ NMR spectrum of $\left[\mathrm{Ag}(2-\mathrm{Me}-\mathrm{imH})_{2}(9\right.$-aca $\left.)\right](2)$ exhibits peaks for the anthracene protons in similar positions to those in the spectra of $\left[\mathrm{Ag}_{2}(9-\mathrm{aca})_{2}\right]$ and $\left[\mathrm{Ag}_{4}(\mathrm{DMSO})_{4}(9-\mathrm{aca})_{4}\right]_{n}$ (1), with additional peaks at 7.08 and $2.47 \mathrm{ppm}$ for the imidazole ring and methyl protons, respectively.

$\left[\mathrm{Ag}(4-\mathrm{Ph}-\mathrm{imH})_{2}(9-\mathrm{aca})\right](3)$ was synthesised from $\left[\mathrm{Ag}_{2}(9-\mathrm{aca})_{2}\right]$ and 4-phenylimidazole (4-Ph-imH) in good yield (81\%) (Scheme 1 ). The IR spectrum of $\mathbf{3}$ contains bands associated with the imidazole and anthracene carboxylate ligands, with the $v_{(\mathrm{O} O \mathrm{O}) \text { asym }}$ and

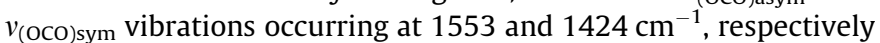
$\left(\Delta_{(\mathrm{OCO})}=129 \mathrm{~cm}^{-1}\right)$. In the ${ }^{1} \mathrm{H}$ NMR spectrum of $(3)$ the signals for the anthracene protons appear in similar positions to those in $\left[\mathrm{Ag}_{2}(9-\mathrm{aca})_{2}\right]$ and complexes 1 and $\mathbf{2}$. Peaks for the 4-Ph-imH protons appear at 7.88, 7.83, 7.59, 7.39 and $7.25 \mathrm{ppm}$ and these are shifted downfield in comparison to those observed in the spectrum of the free ligand. Furthermore, peak integrals indicate that the ratio of 9-aca:4-Ph-imH is 1:2. Thus, these combined IR, NMR and microanalytical data suggest that $\mathbf{3}$ may be structurally similar to [Ag(2-Me-imH $\left.)_{2}(9-a c a)\right](2)$.

Spectral and microanalytical data for $\left[\mathrm{Ag}(2-\mathrm{Mebenz-imH})_{2}(9-\right.$ aca)] (4), which was synthesised in high yield from $\left[\mathrm{Ag}_{2}(9-\mathrm{aca})_{2}\right]$ and 2-methylbenzimidazole (2-Mebenz-imH) in acetonitrile, suggests that this complex is isostructural with $\mathbf{2}$ and $\mathbf{3}$.

In an attempt to recrystallise $\left[\mathrm{Ag}(2-\mathrm{Mebenz}-\mathrm{imH})_{2}(9-\mathrm{aca})\right](4)$ from ethanol the silver-free, monohydrate salt, (2-Mebenz$\left.\mathrm{imH}_{2}\right)(9-\mathrm{aca}) \cdot \mathrm{H}_{2} \mathrm{O}(5)$, crystallised and was subsequently characterised using X-ray crystallography (Fig. 7). The cationic nature of the benzimidazolate was established from difference electron density maps which clearly showed the NH protons. The bond lengths and geometry are as expected for a benzimidazolate cation and carboxylate anion. The water molecules link 9-aca ${ }^{-}$anions into chains parallel to the $a$ axis and the benzimidazolate cations link the chains by hydrogen bonds to water and to one of the carboxylate oxygen atoms (Fig. 8, Table 2). The 2-Mebenz-im $\mathrm{H}_{2}{ }^{+}$cations lie between the 9 -aca ${ }^{-}$anions generating $\pi$-stacked columns, also running parallel to the $a$ axis (Fig. 8) and linking the structure into sheets. The interplanar distances between the mean plane of the benzimidazolate cation and the neighbouring anthracene ring are 3.16 and $3.51 \AA$ (under symmetry operation $x-1, y, z$ ).

$\left[\mathrm{Ag}(2-\right.$ Mebenz-im) $](6)$ was synthesised from $\left[\mathrm{Ag}_{2}(9-\mathrm{aca})_{2}\right]$ and 2-methylbenzimidazole in methanol and the product formed in good yield (79\%) (Scheme 1). The small changes in the reaction

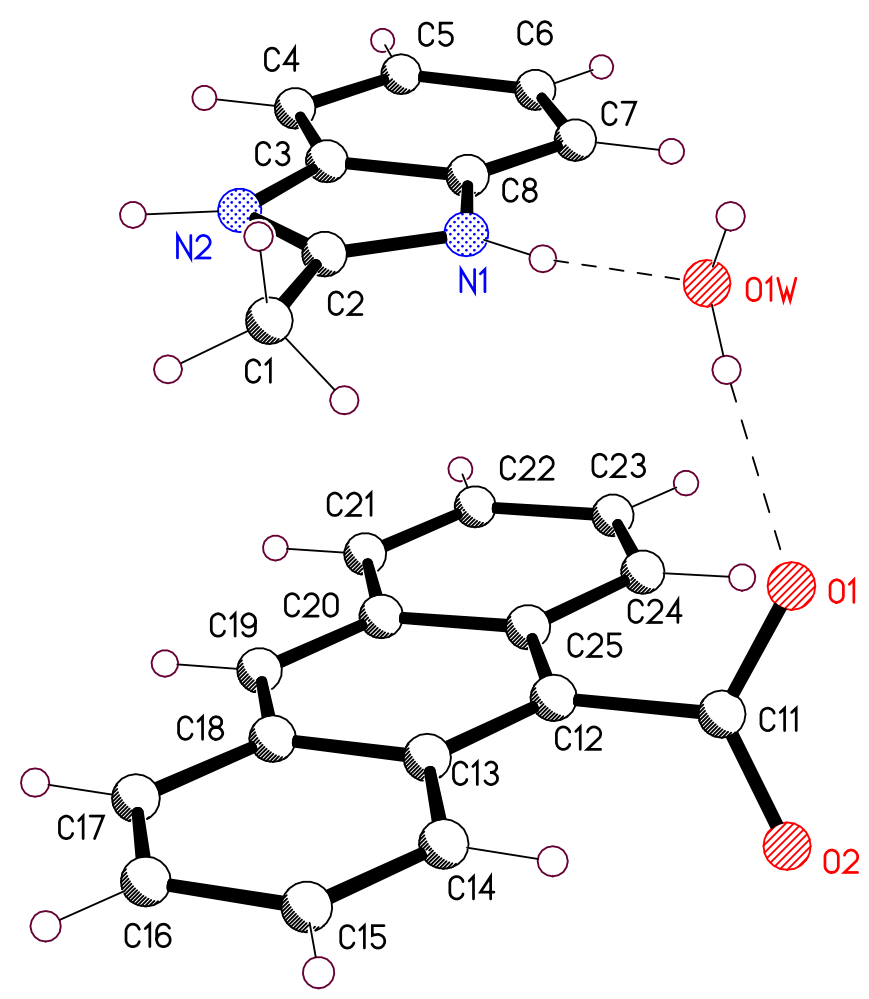

Fig. 7. Perspective view of (2-Mebenz-imH $\left.\mathrm{H}_{2}\right)(9-\mathrm{aca}) \cdot \mathrm{H}_{2} \mathrm{O}$ (5). Dashed lines represent hydrogen bonds. 


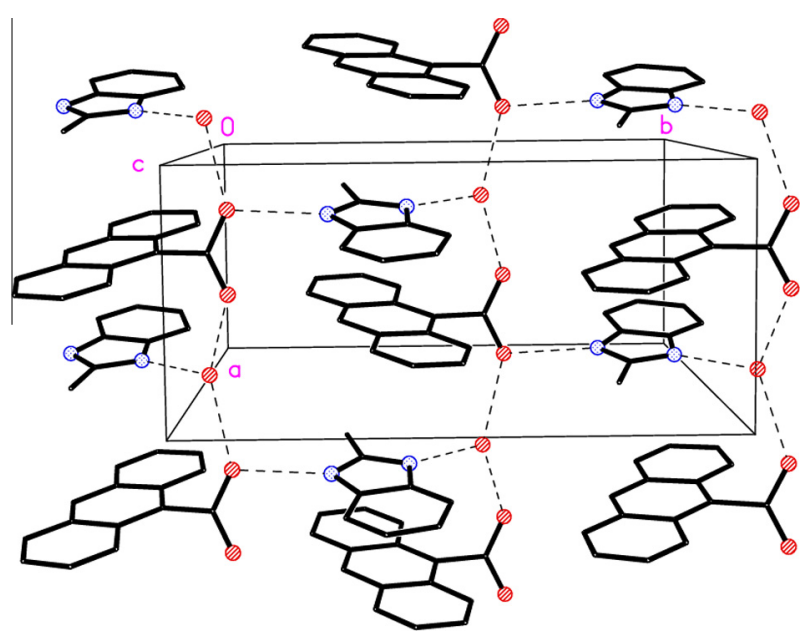

Fig. 8. Packing diagram for 5 showing hydrogen bonds (dashed) and $\pi$-stacking.

conditions, compared to the synthesis of $\left[\mathrm{Ag}_{2}(2-\mathrm{Mebenz}-\mathrm{imH})_{4}\right](9$ aca) $)_{2}$ (4) (methanol as opposed to acetonitrile and elevated temperature), has led to a product that is structurally quite different and an absence of the 9-aca ${ }^{-}$anion. Although the IR spectrum of 6 contained bands for the imidazolate ligand, distinctive bands for the carboxylate moiety were not observed. Microanalytical data indicate a Ag:2-Mebenz-im ratio of $1: 1$ and that the imidazole has been deprotonated at the amine nitrogen $(\mathrm{N}-\mathrm{H})$ atom to form the anion, 2-Mebenz-im ${ }^{-}$.

[Ag(Benz-im)] (7), [Ag(2-Ph-im) $](8)$ and $[\mathrm{Ag}(4,5-\mathrm{CN}-\mathrm{im})](\mathbf{9})$ formulate in a similar manner to $\mathbf{6}$, and the ${ }^{1} \mathrm{H}$ NMR spectrum of the only sparingly soluble complex, $(\mathbf{8})$, contained peaks for the $2-\mathrm{Ph}^{-} \mathrm{im}^{-}$anion and no aca- peaks were observed. It is thought that these largely insoluble materials, (6-9), form as polymeric chains in which the silver is coordinated to the deprotonated amine $\mathrm{N}$ of one imidazolate ligand and the imine nitrogen of a neighbouring imidazolate ligand (Fig. 9). Similar polymeric chains have been reported for the silver(I)-4-nitroimidazolate complex, $\left[\mathrm{Ag}\left(4-\mathrm{NO}_{2}-\right.\right.$ $\mathrm{im})$ ] (4- $\mathrm{NO}_{2}$-imH = 4-nitroimidazole) [15], and also for metal-imidazolate complexes of $\mathrm{Ni}(\mathrm{II}), \mathrm{Cu}(\mathrm{II}), \mathrm{Zn}(\mathrm{II})$ and $\mathrm{Ag}(\mathrm{I})$ [14].

In the syntheses of 1-9 it is interesting to note the influence of the $\mathrm{p} K_{\mathrm{a}}$ of the imidazole ligand and also the reaction solvent. As expected, imidazoles with relatively low $\mathrm{p} K_{\mathrm{a}}$ values (Benz-imH $\mathrm{p} K_{\mathrm{a}}$ $5.4 ; 2-\mathrm{Ph}-\mathrm{imH} \mathrm{p} K_{\mathrm{a}} 5.23 ; 4,5-\mathrm{CN}-\mathrm{imH} K_{\mathrm{a}} 5.2$ ) had a greater tendency to deprotonate (yielding the imidazolate complexes 7, 8 and 9, respectively). The presence of a coordinating metal ion will also lower the $\mathrm{p} K_{\mathrm{a}}$ of the imidazole [16,17]. With 2-Me-imH, 4-Ph-imH and 2-Mebenz-imH ( $\mathrm{p} K_{\mathrm{a}}$ values of $7.75,6.1$ and 6.19 , respectively) the imidazole ligand remains neutral and the respective imidazole/carboxylate complexes, 2, 3 and $\mathbf{4}$, form from $\left[\mathrm{Ag}_{2}(9-\mathrm{aca})_{2}\right]$ when the reactions are conducted in the polar, aprotic solvent, $\mathrm{MeCN}$. In the reaction of $\left[\mathrm{Ag}_{2}(9-\mathrm{aca})_{2}\right]$ with 2-Mebenz-imH the solvent appears to also be an important factor as the protic solvent, $\mathrm{MeOH}$, promotes formation of the imidazolate complex, [ $\mathrm{Ag}(2-\mathrm{Me}-$ benz-im)] (6) and, presumably, the free carboxylic acid, 9-acaH. The

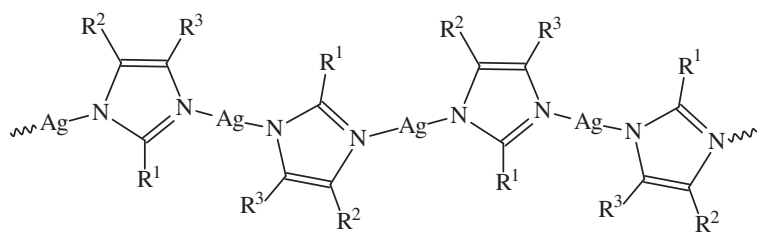

Fig. 9. Proposed polymeric structure for imidazolate complexes 6-9. tenuous nature of $\left[\mathrm{Ag}(2-\mathrm{Mebenz}-\mathrm{imH})_{2}(9\right.$-aca $\left.)\right](4)$ is exemplified by the fact that dissolution in refluxing EtOH causes complex disintegration and formation of the imidazolium salt, (2-Mebenz$\left.\mathrm{imH}_{2}\right)(9-\mathrm{aca})$.

\subsection{Biological activity}

The growth inhibitory effects of the new $\mathrm{Ag}(\mathrm{I})$ complexes, $\mathrm{AgNO}_{3}$ and silver sulphadiazine were investigated against Gramnegative E. coli., Gram-positive MRSA and the fungal pathogen, $C$. albicans (Table 3). For direct comparisons with $\mathrm{AgNO}_{3}$ and silver sulphadiazine the activities (as $\mathrm{MIC}_{50}$ or $\mathrm{MIC}_{100}$ values) are reported as $\mu \mathrm{M}$ concentrations of administered $\operatorname{Ag}(\mathrm{I})$ ion. The metal-free ligands were also screened and all proved to be inactive at the relatively high concentration of $100 \mu \mathrm{g} \mathrm{cm}{ }^{-3}$.

In all cases, the complexes were substantially more active against the fungal cells than the two bacterial species, a pattern which matched that previously observed with the N1-substituted imidazole/9-aca ${ }^{-} \mathrm{Ag}(\mathrm{I})$ complexes [6]. These results are somewhat at variance with those observed for the $\mathrm{Ag}(\mathrm{I})$ complexes containing 2-hydroxymethyl- $N$-alkylimidazole ligands where, dependant on the chain length of the alkyl substituent on the imidazole, the activity against $E$. coli, S. aureus and $B$. spirizizenii exceeded that for C. albicans [5]. In terms of $\mathrm{Ag}(\mathrm{I})$ content, there was no significant difference in the antibacterial and antifungal activities of 1-4 and 6 compared to those of the $\mathrm{Ag}(\mathrm{I})$ complexes containing N1-substituted imidazole and 9-aca ${ }^{-}$ligands [6]. The insoluble, imidazolate complexes, 7-9, were a lot less aggressive towards bacteria than the other $\operatorname{Ag}(\mathrm{I})$ complexes. Complexes 6-8 were the least active against $C$. albicans whilst the other $\mathrm{Ag}(\mathrm{I})$ complexes were $c a$. twice as active as the prescription drug, Ketoconazole $\left(\mathrm{MIC}_{100}=4.70 \mu \mathrm{M}\right)$ [6].

The insect larvae, G. mellonella, was used to conduct in vivo toxicity profiling on the new $\mathrm{Ag}(\mathrm{I})$ complexes and results were compared to an untreated control (no added compound) and also to the reference standards, silver nitrate and ketoconazole. Test solutions/suspensions $\left(100 \mu \mathrm{g} \mathrm{cm}^{-3}\right)$ were injected directly into the haemocoel through the last pro-leg of the insect and survival was monitored after $72 \mathrm{~h}$. Death was confirmed by the lack of movement in response to stimulus together with discolouration of the cuticle. Two types of in vivo antifungal screening protocols were examined: (i) prophylactic treatment and (ii) the treatment of infection (pre-infected larvae). Larvae were infected with a lethal dose of $C$. albicans $\left(2 \times 10^{6}\right.$ fungal cells $)$ in each protocol. For the prophylactic treatment, the test compound was administered $1 \mathrm{~h}$ prior to infection with $C$. albicans cells, while for the treatment of infection experiments the compound was administered $1 \mathrm{~h}$ after infection with C. albicans. Results are given in Table 4.

For the prophylactic treatment, all of the test complexes, with the exception of $\left[\mathrm{Ag}(2-\mathrm{Me}-\mathrm{im})_{2}(9-\mathrm{aca})\right]$ (2), offered a substantially greater chance of survival, in comparison to the untreated control, against infection by a lethal dose of $C$. albicans. When analysed in terms of $\mu \mathrm{g} \mathrm{cm}^{-3}$ of compound, $\mathrm{AgNO}_{3}$ and ketoconazole gave the best protection. $[\mathrm{Ag}(2-\mathrm{Ph}-\mathrm{im})](\mathbf{8})$ proved to be the most efficient of the new $\mathrm{Ag}(\mathrm{I})$ complexes which is somewhat surprising since this complex registered one of the higher $\mathrm{MIC}_{100}$ values $\left(6.21 \mu \mathrm{M} ; 1.56 \mu \mathrm{g} \mathrm{cm}^{-3}\right)$ in the in vitro testing against the fungus. For the treatment of infection, $\mathrm{AgNO}_{3}$ and ketoconazole again offered the best prognosis. Sample $\mathbf{2}$ and the more insoluble materials, 6-9, proved to be the most active of the new complexes.

Overall, the survival rates of larvae treated with $\mathrm{AgNO}_{3}$ were very similar in the prophylactic and the treatment of infection experiments ( $80 \%$ and $75 \%$, respectively). However, whereas complex 2 did not offer significant protection when administered prophlytically (30\% survival) it proved to be extremely beneficial when used to treat larvae that had been pre-infected with C. albi- 
Table 3

Antimicrobial activities of the new $\mathrm{Ag}(\mathrm{I})$ complexes and the positive controls ${ }^{\mathrm{a}}, \mathrm{AgNO}_{3}$ and silver sulfadiazine. $\mathrm{MIC}$ values are given in $\mu \mathrm{M}$ concentrations of $\mathrm{Ag}(\mathrm{I})$ ions.

\begin{tabular}{|c|c|c|c|}
\hline Complex & E. coli $\mathrm{MIC}_{50}\left(\mu \mathrm{M} \mathrm{Ag}^{+}\right)$ & MRSA MIC ${ }_{50}\left(\mu \mathrm{M} \mathrm{Ag}^{+}\right)$ & C. albicans $\mathrm{MIC}_{100}\left(\mu \mathrm{M} \mathrm{Ag}^{+}\right)$ \\
\hline$\left[\mathrm{Ag}_{4}(\mathrm{DMSO})_{4}(9-\mathrm{aca})_{4}\right]_{n}(\mathbf{1})$ & 22.12 & 22.38 & 1.92 \\
\hline$\left[\mathrm{Ag}(2-\mathrm{Me}-\mathrm{imH})_{2}(9-\mathrm{aca})\right](\mathbf{2})$ & 22.87 & 34.54 & 1.58 \\
\hline$\left[\mathrm{Ag}(4-\mathrm{Ph}-\mathrm{imH})_{2}(9-\mathrm{aca})\right](\mathbf{3})$ & 50.21 & 76.08 & 2.53 \\
\hline$\left[\mathrm{Ag}(2-\text {-Mebenz-imH })_{2}(9-\mathrm{aca})\right](4)$ & 25.96 & 29.82 & 2.62 \\
\hline$[\mathrm{Ag}(2-$-Mebenz-im $)](\mathbf{6})$ & 36.14 & 52.21 & 13.07 \\
\hline$[\mathrm{Ag}($ Benz-im $)](7)$ & 138.93 & 171.73 & 6.93 \\
\hline$[\mathrm{Ag}(2-\mathrm{Ph}-\mathrm{im})](\mathbf{8})$ & 149.77 & 76.08 & 6.21 \\
\hline$[\mathrm{Ag}(4,5-\mathrm{CN}-\mathrm{im})](\mathbf{9})$ & 127.22 & 244.49 & 1.73 \\
\hline $\mathrm{AgNO}_{3}$ & 65.19 & 34.32 & 1.83 \\
\hline Silver sulfadiazine & 73.05 & 50.20 & \\
\hline
\end{tabular}

$\mathrm{MIC}_{100}$ for Ketoconazole against C. albicans is $4.70 \mu \mathrm{M}[6]$

a Previously published [6].

\section{Table 4}

Survival (\%) of G. mellonella larvae $72 \mathrm{~h}$ after being infected with a lethal dose of $C$. albicans $\left(2 \times 10^{6}\right.$ fungal cells). For prophylactic treatment, the test compound was administered $1 \mathrm{~h}$ prior to infection with $C$. albicans cells, while for the treatment of infection experiments the compound was administered $1 \mathrm{~h}$ after infection with the fungal cells. Compounds were administered at a concentration of $100 \mu \mathrm{g} \mathrm{cm}^{-3}$ ). Data for the control, silver nitrate and ketoconazole have previously been published [6].

\begin{tabular}{llll}
\hline Test compound & Dosage $\mu \mathrm{cm}^{-3}\left(\mu \mathrm{mol} \mathrm{Ag}(\mathrm{I}) \mathrm{cm}^{-3}\right)$ & \% Survival & Treatment of infection \\
\cline { 3 - 4 } & & Prophylactic & 10 \\
\hline Control & & 10 & 75 \\
Ketoconazole & $100(0)$ & 75 & 75 \\
Silver nitrate & $100(0.59)$ & 80 & 30 \\
$\mathbf{1}$ & $100(0.49)$ & 50 & 70 \\
$\mathbf{2}$ & $100(0.20)$ & 30 & 20 \\
$\mathbf{3}$ & $100(0.21)$ & 45 & 10 \\
$\mathbf{4}$ & $100(0.22)$ & 40 & 50 \\
$\mathbf{6}$ & $100(0.42)$ & 40 & 50 \\
$\mathbf{7}$ & $100(0.44)$ & 60 & 60 \\
$\mathbf{8}$ & $100(0.39)$ & 70 & 60 \\
$\mathbf{9}$ & $100(0.44)$ & 60 & \\
\hline
\end{tabular}

cans (70\% survival). This suggests that there may be substantial degradation of the complex in the $1 \mathrm{~h}$ timeframe between complex administration and inoculation with the lethal dose of fungal cells. This trend contrasted with that of complex 4 (40\% prophylactic, $10 \%$ treatment of infection).

The trends found for the two sets of in vivo experiments using $G$. mellonella closely reflect those observed using $\mathrm{Ag}(\mathrm{I})$ 9-anthracene carboxylate complexes containing N1-substituted imidazoles [6], where again, $\mathrm{AgNO}_{3}$ proved to be the most effective agent. This implies that the position of substituents on the imidazole ring does not impact greatly on the activity of the $\mathrm{Ag}(\mathrm{I})$ complex.

In the current work, when the survival figures are analysed with respect to the $\operatorname{Ag}(\mathrm{I})$ ion content of each complex it is evident that complexes $\mathbf{3}$ and $\mathbf{2}$ performed the best in the prophylactic and treatment of infection experiments, respectively (activities are $\mathrm{ca}$ 1.5 and 3 times that of $\left.\mathrm{AgNO}_{3}\right)$. In terms of $\mathrm{Ag}(\mathrm{I})$ ion content, $\left[\mathrm{Ag}_{4}(-\right.$ DMSO $\left.)_{4}(9-\text { aca })_{4}\right]_{n}(\mathbf{1})$, which does not contain an imidazole ligand, returned one of the poorest performances.

\section{Conclusions}

$\left[\mathrm{Ag}_{2}(9-\mathrm{aca})_{2}\right]$ reacts with DMSO and a selection of substituted imidazoles giving $\left[\mathrm{Ag}_{4}(\mathrm{DMSO})_{4}(9-\mathrm{aca})_{4}\right]_{n}(\mathbf{1}),\left[\mathrm{Ag}(2-\mathrm{Me}-\mathrm{imH})_{2}(9-\right.$ aca) $(2),\left[\mathrm{Ag}(4-\mathrm{Ph}-\mathrm{imH})_{2}(9-\mathrm{aca})\right]$ (3), [Ag(2-Mebenz-imH $)_{2}(9-$ aca)] (4), [Ag(2-Mebenz-im)] (6), [Ag(Benz-im)] (7), [Ag(2-Phim)] (8) and $[\mathrm{Ag}(4,5-\mathrm{CN}-\mathrm{im})](\mathbf{9})$. In the carboxylate/imidazole complexes 2-4, the imidazole ligand remains neutral, whilst in 6-9 the imidazolate ligand deprotonates and no carboxylate ligand is present. Refluxing $\mathbf{4}$ in EtOH gives the metal-free, imidazolium salt, 2-Mebenz-imH $\left.\mathrm{H}_{2}\right)(9$-aca $) \cdot \mathrm{H}_{2} \mathrm{O}(\mathbf{5})$. The $\mathrm{Ag}(\mathrm{I})$ complexes are very active against $C$. albicans, and moderately active against MRSA and
E. coli. A number of the complexes offer a good prognosis for $G$. mellonella infected with a lethal dose of $C$. albicans cells.

\section{Appendix A. Supplementary data}

CCDC 920488-920490 contain the supplementary crystallographic data for compounds $\mathbf{1}, \mathbf{2}$, and $\mathbf{5}$, respectively. These data can be obtained free of charge via http://www.ccdc.cam.ac.uk/conts/retrieving.html, or from the Cambridge Crystallographic Data Centre, 12 Union Road, Cambridge CB2 1EZ, UK; fax: (+44) 1223336-033; or e-mail: deposit@ccdc.cam.ac.uk. Supplementary data associated with this article can be found, in the online version, at http://dx.doi.org/10.1016/j.poly.2013.03.057.

\section{References}

[1] Bulletin of the World Health Organization 89 (2011) 88

[2] The evolving threat of antimicrobial resistance - options for action, WHO Patient Safety Programme, (c) World Health, Organization, 2012.

[3] A.B.G. Lansdown, Silver in Healthcare - Its Antimicrobial Efficacy and Safety in Use, The Royal Society of Chemistry, Issues in Toxicology No. 6, Cambridge, UK, 2010.

[4] W.-R. Li, X.-B. Xie, Q.-S. Shi, H.-Y. Zeng, Appl. Microbiol. Biotechnol. 85 (2010) 1115.

[5] P. Kleyi, R.S. Walmsley, M.A. Fernandes, N. Torto, Z.R. Tshentu, Polyhedron 41 (2012) 25.

[6] M. McCann, R. Curran, M. Ben-Shoshan, V. McKee, A.A. Tahir, M. Devereux, K. Kavanagh, B.S. Creaven, A. Kellett, J. Chem. Soc., Dalton Trans. 41 (2012) 6516.

[7] G.M. Sheldrick, Acta Crystallogr., Sect. A 64 (2008) 112.

[8] A.P. Desbois, P.J. Coote, Adv. Appl. Microbiol. 78 (2012) 25.

[9] R. Rowan, C. Moran, M. McCann, K. Kavanagh, Biometals 22 (2009) 461.

[10] R. Rowan, T. Tallon, A.M. Sheahan, R. Curran, M. McCann, K. Kavanagh, M. Devereux, V. McKee, Polyhedron 25 (2006) 1771.

[11] R. Curran, J. Lenehan, M. McCann, K. Kavanagh, M. Devereux, D.A. Egan, G. Clifford, K. Keane, B.S. Creaven, V. McKee, Inorg. Chem. Commun. 10 (2007) 1149. 
[12] Spectroscopic Tools <http://www.science-and-fun.de/tools/>.

[13] G.B. Deacon, R.J. Phillips, Coord. Chem. Rev. 33 (1980) 227.

[14] Y. Kachkurova, Theor. Exp. Chem. 3 (1967) 498.

[15] I. Segalas, A.L. Beauchamp, Can. J. Chem. 70 (1992) 943.
[16] J. Alí-Torres, L. Rodríguez-Santiago, M. Sodupe, Phys. Chem. Chem. Phys. 13 (2011) 7852.

[17] R.B. Martin, Proc. Nat. Acad. Sci. U.S.A. 71 (1974) 4346. 